\title{
Effect of Different Doses of Granisetron on Preventing Postoperative Shivering in Patients undergoing Septorhinoplasty under General Anesthesia
}

Reza Movassaghi Gargari', Hassan Mohammadi Poor Anvari*

1. Department of Anesthesiology, Tabriz University of Medical Sciences, Tabriz, Iran

\begin{abstract}
Background: Postoperative shivering is a frequent complication in recovery room after general anesthesia and has been reported in $40-70 \%$ of patients undergoing surgery. Postoperative shivering might cause hypoxemia, increase in oxygen consumption, a linear increase in carbon dioxide production, lactic acidosis, and increased intraocular pressure and intracranial pressure. The aim of this study was to compare the effects of different doses of granisetron on preventing postoperative shivering in patients undergoing septorhinoplasty under general anesthesia. Methods: 90 patients aged 18-60 years old with grades I or II of American Society of Anesthesiologists (ASA) physicals classification were allocated to the study. The first group (G1) received Granisetron 1mg Intra Venous (IV) before anesthesia induction; the second group (G2) received $3 \mathrm{mg}$ Granisetron IV before anesthesia induction and the last group, the control group, received Normal Saline (NS). Three groups were matched regarding age, gender, weight and duration of surgery. Shivering grade and time of operation were recorded in the recovery room. Results: 90 patients scheduled for septorhinoplasty, including 54 men and 36 women, were enrolled to the study. The mean age of the patients was $28.53 \pm 8.62(18-60)$ years. The number of the patients suffering from shivering in the recovery room was significantly less in group $\mathrm{G} 2$ rather than control group $(P=0.006)$ and also need to therapy was significantly less in this group (G2) compared with the control group ( $P=0.002)$.

Conclusion: Prophylactic use of granisetron $(3 \mathrm{mg}, \mathrm{IV})$ can be effective in preventing postoperative shivering following septorhinoplasty.
\end{abstract}

Keywords: Granisetron; Shivering; General Anesthesia;

Corresponding author:

Hassan Mohammadi Poor Anvari

Department of Anesthesiology, Tabriz University of Medical Sciences, Tabriz, Iran

Email: dr.anvari22@yahoo.com Phone: 00989188112210

Receive date: 2017-01-26 | Accept date: 2017-03-12 | Publish date: 2017-04-08

DOI: 10.7575/aiac.abcmed.17.05.02.04 


\section{Introduction}

Postoperative shivering is one of the most common side effects following anesthesia. The prevalence of shivering has been reported to be about $40-70 \%$ in different patients (1) and it can be related to the age, gender, anesthetics, temperature of the operative room and the operation period (2). Postoperative shivering which is accompanied by vasoconstriction of skin circulation occurs due to hypothermia throughout the operation. This is a physiologic mechanism to preserve body temperature (34). Central neuroaxial blockage and general anesthesia can cause hypothermia and shivering. Perioperative hypothermia is the most common cause of shivering (4). Postoperative shivering is associated with an unpleasant experience in patients. Increase in oxygen consumption, arterial hypoxia and carbon dioxide production can contribute to acid and base abnormalities (5). It can also cause some other abnormalities like: increase in intraocular pressure (IOP) and intracranial pressure (ICP), and abnormalities in Pulse Rate $(P R)$, Blood Pressure (BP), peripheral capillary oxygen saturation (SpO2) and Electrocardiography (ECG) (1). Shivering can impose further pressure on cardiac function through increasing oxygen consumption in patients with reduced cardiopulmonary reserve or coronary artery diseases (6). Furthermore, this event exacerbates incisional pain, delays incision healing, increases hospital costs and hospital stay and delays Post Anesthesia Care Unit (PACU) discharge. Thus, preventing these hazardous side effects seems logical. Some pharmacological and non- pharmacological interventions have been proposed to prevent shivering. Some pharmacological treatment such as clonidine, tramadol, neostigmine, dexmethodine, magnesium sulfate, ketamine, narcotics have been reported to be effective (1, 8). Granisetron is a $5 \mathrm{HT} 3$ receptor antagonist that can prevent vomiting and nausea after operation (11-12). In a study by lqbal et al., it was shown that granisetron can be effective in treating postoperative shivering (8). The aim of this study was to compare the effects of different doses of granisetron on preventing postoperative shivering in patients undergoing septorhinoplasty under general anesthesia.

\section{Methods}

Our study was a clinical trial that was approved by the ethics committee of Tabriz University of Medical Sciences, Tabriz, Iran and registered in Iranian Registry of Clinical Trial (IRCT) with the code number: IRCT201411173915N12. The trial was conducted in Imam Reza Hospital, Tabriz University of Medical Sciences, Tabriz, Iran in a 12-month period (January 2014 to December 2014). Written informed consents were obtained from patients prior to enrollment. 90 patients aged $18-60$ years old with ASA grade I or II scheduled for septorhinoplasty under general anesthesia were allocated to the study. Subjects were randomly divided into three groups (Each group consisted of 30 patients) using computer randomization software. Exclusion criteria from the study were: Patients with the history of cardiopulmonary diseases, concurrent infection, body temperature of more than $380 \mathrm{C}$ or less than $36.50 \mathrm{C}$ and hypersensitivity to serotonin antagonists. Body temperature was measured through the tympanic membrane in the operation room. The first group (G1) received granisetron $1 \mathrm{mg}$ Intra Venous (IV) with 5cc NS before anesthesia induction; the second group (G2) received $3 \mathrm{mg}$ granisetron IV in $5 c c$ NS before induction and the last group, control group, received only $5 c c$ of Normal Saline (NS). All groups underwent the same standard general anesthesia and were matched regarding age, gender, weight, operation room condition, volume and 


\begin{tabular}{cc}
\hline Score/ grade & Clinical signs \\
\hline 0 & $\begin{array}{c}\text { No shivering } \\
\text { Piloerection but no visible } \\
\text { shivering } \\
2\end{array}$ \\
3 & $\begin{array}{c}\text { Muscular activity only one } \\
\text { muscle group } \\
\text { Muscular activity more than } \\
\text { one muscle group } \\
\text { Shivering involve the whole } \\
\text { body }\end{array}$ \\
\hline
\end{tabular}

Table 1: Classification of shivering

temperature of administered fluids, body coverage during and after surgery and duration of surgery. All patients were under ASA standard monitoring (SpO2, NIBP, HR, EtCO2 and body temperature). All patients received fentanyl $2 \mu \mathrm{g} / \mathrm{kg}$ and midazolam $0.03 \mathrm{mg} / \mathrm{kg}$ as premedication and propofol $2 \mathrm{mg} / \mathrm{kg}$ and cisatracurium $0.15 \mathrm{mg} / \mathrm{kg}$ for anesthesia induction. Anesthesia maintenance was performed with Total Intravenous Anesthesia (TIVA) using infusion of propofol and remifentanil. Shivering grade, nausea, vomiting and the period of operation were recorded every 5 minutes by a single anesthesiologist in the recovery room. Shivering grade of the patients has been shown in Table1. In case of shivering, patients were kept warm for 10 minutes at first and if shivering did not resolve, they received pethidine $25 \mathrm{mg}$ IV up to three times every 20 minutes. Response to treatment was controlled every 5 minutes. Patients with grade 3 intensity of shivering or higher were treated. Statistical Analysis: Data were given as mean \pm standard deviation (SD). Chi-square test (qualitative data), Independent samples Kruskal-Walis test and t test (quantitative data) were used for comparisons. Statistical analysis was performed using SPSS software (SPSS, USA). $P$ value $\leq 0.05$ was regarded statistically significant.

\section{Results}

90 patients scheduled for septorhinoplasty, including 54 men and 36 women were enrolled to the study. The mean age of the patients was $28.53 \pm 8.62(18-60)$ years. Comparison of the three groups was made based on the mean age, weight and duration of surgery, blood pressure (BP) and Heart Rate (HR) (Table 2). Comparison between three groups in terms of $H R, B P$, need for treatment, shivering, time of shivering occurrence after surgery are presented in Table 3. In terms of post-operative shivering, there was significant difference between $\mathrm{G} 2$ that received $3 \mathrm{mg}$ granisetron and control group ( $P=0.006)$; however, there was no significant relation between $\mathrm{G} 1$ and control groups. There was significant correlation between $\mathrm{G} 2$ and control groups $(\mathrm{P}=0.018)$ and $\mathrm{G} 1$ and control groups ( $\mathrm{P}=0.002)$ in terms of need for treatment after shivering. There was no significant difference between three groups in terms of HR and BP. There were 18 patients in $\mathrm{G} 1$ and 21 patients in $\mathrm{G} 2$ groups that did not experience shivering after surgery (Table 4). There were only 3 patients in $\mathrm{G} 2$ group that experienced shivering and did not response to active warming; they were treated with a single of pethidine (Table 5). There was no significant correlation between three groups in terms of the onset time of shivering after surgery (Table $6)$.

\section{Discussion}

In this study, it was demonstrated that granisetron can be effective in preventing postoperative shivering. Shivering is an important concern in patients after surgery and increases oxygen uptake and could cause arterial hypoxia and lactic acidosis in patients. Furthermore, it can interfere with ECG 


\begin{tabular}{ccccccc}
\hline & Mean age & Weight $(\mathbf{k g})$ & $\begin{array}{c}\text { Diastolic } \\
\text { period of } \\
\text { operation }\end{array}$ & $\begin{array}{c}\text { Systolic blood } \\
\text { plood } \\
\text { pressure }\end{array}$ & Heart rate \\
\hline G1 & $26.23 \pm 8.28$ & $68.23 \pm 11.89$ & $1.92 \pm 0.79$ & $77.8 \pm 5.02$ & $123.77 \pm 7.05$ & $77.17 \pm 10.61$ \\
G2 & $28.1 \pm 7.78$ & $71.43 \pm 12.36$ & $2.41 \pm 0.60$ & $77.57 \pm 8.93$ & $122.8 \pm 11.46$ & $78.6 \pm 12.54$ \\
$\begin{array}{c}\text { Control } \\
\text { group }\end{array}$ & $31.27 \pm 9.81$ & $69.57 \pm 9.3$ & $2.26 \pm 0.58$ & $82.13 \pm 5.55$ & $122.83 \pm 6.62$ & $80.73 \pm 9.44$ \\
\hline
\end{tabular}

Table 2: Comparison of three groups based on the mean age, weight and the period of operation. Data are presented as mean \pm standard deviation monitoring. Therefore, preventing shivering in the elderly patients with low cardiopulmonary reserve is of great importance (8). In this study, was $60 \%$ and grade 3 or higher shivering was seen in $43 \%$ of the patients which was different from the previous similar studies $(2,8,15)$. the incidence of shivering in the control group

\begin{tabular}{ccccccc}
\hline & $\begin{array}{c}\text { Diastolic blood } \\
\text { pressure } \\
(\mathbf{P} \text {-value) }\end{array}$ & $\begin{array}{c}\text { Systolic blood } \\
\text { pressure } \\
(\mathbf{P} \text {-value) }\end{array}$ & $\begin{array}{c}\text { Heart rate } \\
(\mathbf{P} \text {-value) }\end{array}$ & $\begin{array}{c}\text { Need for } \\
\text { treatment } \\
\text { after } \\
\text { shivering }(\mathbf{P}- \\
\text { value) }\end{array}$ & $\begin{array}{c}\text { Shivering (P- } \\
\text { value) }\end{array}$ & $\begin{array}{c}\text { Time of } \\
\text { shivering } \\
\text { after } \\
\text { surgery (p- } \\
\text { value) }\end{array}$ \\
\hline G1 and G2 & 0.058 & 0.549 & 0.517 & 0.430 & 0.389 & 0.583 \\
$\begin{array}{c}\text { G1 and control } \\
\text { group }\end{array}$ & 0.478 & 0.737 & 0.745 & 0.018 & 0.053 & 0.293 \\
$\begin{array}{c}\text { G2 and control } \\
\text { group }\end{array}$ & 0.081 & 0.543 & 0.328 & 0.002 & 0.006 & 0.066 \\
\hline
\end{tabular}

Table 3: Comparison of P-value of three groups based on DBP, SBP and HR. The numbers indicate p-value

Age and duration of surgery have been reported to be important risk factors of postoperative shivering (8). In this study, patients over 60 years old were excluded. In statistical analysis, there were no significant differences in terms of age, the time of operation, gender and weight in three groups. Post-operative shivering and need for treatment were significantly lower in patients who received $3 \mathrm{mg}$ granisetron vs. control group. Iqbal et al. demonstrated that shivering after laparoscopy under general anesthesia was lower in patients having received granisetron $40 \mu / \mathrm{kg}(8)$. In a similar study, Sagir et al. showed that shivering was lower in patients undergoing urological surgery and received granisetron (11). In 40 children who received 10 $\mu / \mathrm{kg}$ granisetron, there was no postoperative shivering (12). Sajedi et al. confirmed these results in a study performed on 132 patients undergoing orthopedic surgery. Shivering was lower in patients who received $40 \mu \mathrm{g} / \mathrm{kg}$ granisetron in comparison to the control group (13). Generali et al. demonstrated that receiving $3 \mathrm{mg}$ granisetron had an important effect in reducing postoperative shivering (14). These results were confirmed by Mahmoud et al. study. They realized that shivering was 


\begin{tabular}{cccc}
\hline & $\begin{array}{c}\text { G1 } \\
\text { (patients) }\end{array}$ & $\begin{array}{c}\text { G2 } \\
\text { (patients) }\end{array}$ & $\begin{array}{c}\text { Control } \\
\text { group } \\
\text { (patients) }\end{array}$ \\
\hline No shivering & 18 & 21 & 12 \\
Piloerection & 4 & 3 & 3 \\
One muscle & 3 & 3 & 2 \\
More than & 4 & 3 & 11 \\
one Muscle & 1 & 0 & 2 \\
Whole body & & & \\
\hline
\end{tabular}

Table 4: Compassion of three groups in term of post-operative shivering. The numbers show the patients

significantly lower in patients receiving granisetron (15). In this study, $1 \mathrm{mg}$ granisetron had no significant effect on the postoperative shivering. It seems that low doses of granisetron are able to reduce postoperative shivering in patients but not considerably affect the rate of occurrence. The onset time of shivering in previous studies was not studied. Based on the results obtained from our study, either $1 \mathrm{mg}$ or $3 \mathrm{mg}$ granisetron compared to the placebo had no significant effect on the onset time of shivering.

\begin{tabular}{cccc}
\hline & G1 & G2 & $\begin{array}{c}\text { Control } \\
\text { group }\end{array}$ \\
\hline $\begin{array}{c}\text { No therapy } \\
1 \text { dose } \\
\text { therapy } \\
2 \text { dose } \\
\text { therapy }\end{array}$ & 25 & 27 & 16 \\
$\begin{array}{c}\text { 3 dose } \\
\text { therapy }\end{array}$ & 0 & 3 & 6 \\
\hline
\end{tabular}

Table 5: Numbers of patients need for treatment after surgery

\begin{tabular}{ccccc}
\hline & $\begin{array}{c}5 \text { min } \\
\text { (patients } \\
\text { ) }\end{array}$ & $\begin{array}{c}\mathbf{1 0} \text { min } \\
\text { (patients } \\
\text { ) }\end{array}$ & $\begin{array}{c}\mathbf{1 5} \text { min } \\
\text { (patients }\end{array}$ & $\begin{array}{c}\mathbf{2 0} \text { min } \\
\text { (patients } \\
\text { ) }\end{array}$ \\
\hline G1 & 4 & 4 & 4 & 0 \\
G2 & 5 & 2 & 0 & 2 \\
Contro & 7 & 8 & 3 & 0 \\
I group & & & & \\
\hline
\end{tabular}

Table 6: The time of shivering after surgery. The Numbers indicate the number of patients

\section{Conclusion}

Prophylactic use of granisetron (3mg, IV) can be effective in preventing postoperative shivering following septorhinoplasty surgery.

\section{References}

1- Joshi SS, Arora A, George A, Vinayak SR. Comparison of intravenous butorphanol, ondansetron and tramadol for control of shivering during regional anesthesia. J anesth Pain and Intensive Care 2013; 17(1):33-39

2- Abdollahi MH, Forouzannia SK, Bagherinasab M, Barzegar K, Fekri A, Sarebanhassanabadi M, Entezari A. The effect of ondansetron and meperedin on preventing shivering after off-pump coronary artery bypass graft. Acta Med Iran 2012;50(6): 395-398

3- Witte JD, Sessler DI. Perioperative shivering: physiology and pharmacology. Anesthesiology 2002;96:467-484

4- Taqi A. Can you stop shivering doctor? J Anesth Pain \& Care 2013;17(1):4-5

5- Dal D, Kose A, Honca M, Akinci SB, Basgul E, Aypar U. Efficacy of prophylactic ketamine in preventing postoperative shivering. Br J Anesth 2005;95:189-192

6- Buggy DJ, Crossley AWA. Thermoregulation, mild perioperative hypothermia and post-anesthetic shivering. Br J Anesth 2000;84:615-628

7- Eydi M, Golzari SE, Aghamohammadi D, Kolahdouzan K, Safari S, Ostadi Z. Postoperative Management of Shivering: A Comparison of Pethidine vs. Ketamine. Anesth Pain Med. 2014; 4(2):e15499. doi: 10.5812/aapm.15499. 
8- Iqbal A, Ahmed, A Rudra, Wankhede RG, Sengupta S, Das T, Roy D. Prophylactic Granisetron Vs Pethidine for the Prevention of Postoperative Shivering: A Randomized Control Trial. Indian Journal Anesth 2009;53(3):330-334 9- Fuji Y, Tanka H, Tokooya H. Granisetron prevents nausea and vomiting during spinal anesthesia for caesarean section. Acta Anansthesiol Scand 1998;42:312-315

10- Biwas BN, Rudka A. Comparison of granisetron and granisetron plus dexamethasone for prevention of prospective nausea and vomiting after laparoscopic cholecystectomy. Acta Anasthesiol Scand 2003;47:79-83

11- Katyal S, Tewari A. Shivering: anesthetic considerations. J Anesth Clin Pharmacol 2002;18:363-376

12- Eldaba AA, Amir YM. Premedication with granisetron reduces shivering during spinal anesthesia in children.

Anesth Intensive Care 2012;40(1):150-153

13- Sajedi P, Yaraghi A, Moseli HA. Efficacy of granisetron in preventing postanesthetic shivering. Acta Anesthesiol Taiwan 2008;46(4):166-170

14- Generali J, Cada D. Off-label drug uses granisetron: Postanesthetic shivering. Hospital Pharmacy 2007;42(5):424427

15- Mahmud AM, Zaki MA. Granisetron Reduces shivering after general anesthesia. Med J Cairo Univer 2013;81(2):127-131 